\title{
KARAKTERISTIK PENGGUNAAN INSULIN PADA PASIEN DIABETES MELLITUS TIPE II DENGAN GANGGUAN GINJAL DI INSTALASI RAWAT INAP RSUD A.W. SJAHRANIE SAMARINDA
}

\author{
Retri Atika, Muhammad Amir Masruhim, Victoria Yulita F. \\ Laboratorium Penelitian dan Pengembangan FARMAKA TROPIS \\ Fakultas Farmasi Universitas Mulawarman, Samarinda, Kalimantan Timur \\ *Email: retriatika@yahoo.com
}

\begin{abstract}
ABSTRAK
Diabetes Mellitus dapat menyebabkan komplikasi diantaranya nefropati diabetika yang dapat berakhir sebagai gagal ginjal. Salah satu terapi yang biasa digunakan untuk pasien Diabetes Mellitus disertai komplikasi adalah dengan penggunaan insulin. Sehingga kita perlu mengetahui jenis insulin dan penggunaan insulin yang sesuai untuk pasien Diabetes Mellitus dengan komplikasi gangguan ginjal. Tujuan penelitian ini adalah untuk mengetahui karakteristik pasien DM tipe II dengan gangguan ginjal dan untuk mempelajari penggunaan insulin pada pasien DM tipe II dengan gangguan ginjal. Penelitian ini menggunakan metode cohort bersifat prospektif dengan teknik sampel (purposive sampling) yaitu pemilihan sampel dimana peneliti langsung memilih sampel yang telah ditentukan (sesuai dengan kriteria inklusi dan eklusi). Dimana data diperoleh dari rekam medik pasien yang sedang menjalani pengobatan di instalasi rawat inap Rumah Sakit A.W. SJAHRANIE dan dilakukan wawancara terhadap pasien. Dari hasil penelitian diketahui bahwa karakteristik pasien Diabetes Mellitus di RSUD A.W. SJAHRANIE meliputi paling banyak 70\% berjenis kelamin perempuan, dengan usia 50-60 tahun sebesar 45\%, riwayat penyakit terdahulu adalah DM sebanyak 30\%, lama pasien menderita penyakit DM 5-10 tahun sebesar $40 \%$, jenis pekerjaan pasien yaitu ibu rumah tangga sebanyak $60 \%$, dan jenis pendidikan terakhir pasien adalah sekolah dasar (SD) sebesar 55\%. Pasien DM tipe II dengan gangguan ginjal diketahui paling banyak menggunakan insulin apidra dengan persentase $25 \%$, untuk penggunaan insulin levemir dan novorapid masing-masing sebesar $15 \%$ dan $20 \%$ dan penggunaan insulin yang paling sedikit adalah insulin lantus dengan persentase $5 \%$. Terdapat 50\% pasien yang tidak menggunakan insulin, hal ini dikarenakan nilai GDS pasien yang masih di batas nilai normal.
\end{abstract}

Kata Kunci : Insulin, Diabetes Mellitus, gangguan ginjal

\section{ABSTRACT}

Diabetes mellitus can lead to complications including nephropathy diabetic to end up as kidney failure. One commonly used therapy for patients with complications of Diabetes Mellitus is with the use of insulin. So we need to know the type of insulin and appropriate use of insulin for diabetes mellitus patients with complications of renal impairment. The purpose of this study was to determine the characteristics of type II DM patients with renal impairment and to examine the use of insulin in diabetes patients type II with renal impairment. This research used a prospective cohort with a purposive sampling techniques, the choice of the sample in which the researcher directly select the 
sample that has been determined (in accordance with the inclusion and exclusion criteria). Where the data obtained from the medical records of patients who are undergoing medical treatment in inpatient hospital A.W. SJAHRANIE and conducted interviews with the patients. The result showed that the characteristics of patients with Diabetes Mellitus in hospitals A.W. Sjahranie covers at most 70\% are female and aged 50-60 years by 45\%, record of previous disease is diabetes by $30 \%$. the length of time patients suffering from DM of 5-10 years at 40\%, the type of work the patient is a housewife as much as 60\%, and the type of the last patient education is primary school by 55\%. Type II diabetes patients with renal impairment is known most widely used insulin Apidra with a percentage of $25 \%$, for the use of insulin Levemir and novorapid respectively by $15 \%$ and $20 \%$ and the use of insulin is insulin Lantus least the percentage of 5\%. There are 50\% of patients not using insulin, this is because the value of GDS patients who were at the limit of the normal value.

Keywords : Insulin, Diabetes Mellitus, Kidney stones

\section{PENDAHULUAN}

Diabetes Mellitus merupakan kondisi kronik yang terjadi karena tubuh tidak dapat memproduksi insulin secara normal atau insulin tidak dapat bekerja secara efektif. Insulin merupakan hormon yang dihasilkan oleh pankreas dan berfungsi untuk memasukkan glukosa yang diperoleh dari makanan ke dalam sel yang selanjutnya akan diubah menjadi energi yang dibutuhkan oleh otot dan jaringan untuk bekerja sesuai fungsinya. Seseorang yang terkena Diabetes Melitus tidak dapat menggunakan glukosa secara normal dan glukosa akan tetap pada sirkulasi darah yang akan merusak jaringan. Kerusakan ini jika berlangsung kronis akan menyebabkan terjadinya komplikasi, seperti penyakit kardiovaskular, nefropati, retinopati, neuropati dan ulkus pedis (International Diabetes Federation, 2012).

Diabetes melitus (DM) termasuk salah satu penyakit degeneratif yang memerlukan penanganan seksama. WHO memprediksi kenaikan jumlah penderita dari 8,4 juta pada tahun 2000 menjadi sekitar 21,3 juta pada tahun 2030 serta paling banyak terjadi pada masyarakat urban dengan gaya hidup yang tidak sehat. Indonesia berada diperingkat keempat jumlah penyandang DM di dunia setelah Amerika Serikat, India, dan Cina. Menurut data Riset Kesehatan Dasar (Riskesdas) tahun 2007, sebaran penderita DM di Indonesia melebihi $1,5 \%$ penduduk terdapat di daerah Sumatera Utara, Jawa Timur, dan Sulawesi Utara.

Komplikasi yang sering terjadi yaitu nefropati diabetika yang dapat berakhir sebagai gagal ginjal. Diabetes mempengaruhi pembuluh darah kecil ginjal akibatnya efisiensi ginjal untuk menyaring darah terganggu. Pasien dengan nefropati menunjukan gambaran ginjal menahun seperti lemas, mual, pucat sampai keluhan sesak napas akibat penimbunan cairan (Misnadiarly, 2006).

Pasien DM dengan komplikasi berat seperti gangguan ginjal sebagian besar tidak lagi menggunakan terapi Antidiabetik oral (OAD), hal ini dikarenakan kemampuan ginjal yang menurun untuk dapat mengekskresi obat di dalam tubuh, sehingga terapi yang biasa digunakan untuk pasien DM dengan gangguan ginjal adalah terapi insulin karena langsung menuju pembuluh darah dan di distribusi ke seluruh tubuh tanpa melewati proses disentegrasi, absorbsi dan eksresi di ginjal.

Penggunaan insulin haruslah tepat dan sesuai dengan indikasi untuk pasien DM dengan gangguan ginjal. Oleh karena itu penelitian ini bertujuan untuk mengkaji jenis insulin yang tepat dan mengkaji penggunaan insulin untuk pasien DM tipe II dengan gangguan ginjal di instalasi rawat inap RSUD A.W. Sjahranie. 


\section{METODE}

Jenis penelitian yang digunakan dalam penelitian ini merupakan penelitian non eksperimental dengan rancangan penelitian menggunakan metode cohort bersifat prospektif. Penelitian ini bersifat non eksperimental karena tidak ada perlakuan pada subyek penelitian. Rancangan penelitian menggunakan metode cohort yaitu penelitian yang dilakukan dengan mengikuti perkembangan pasien sejak awal masuk rumah sakit hingga keluar dari rumah sakit (follow up pasien). Penelitian ini bersifat prospektif, pengambilan data dilakukan melalui wawancara kepada pasien yang sedang menjalani pengobatan di instalasi rawat inap RSUD Abdul Wahab Sjahranie Samarinda dengan diagnosa Diabetes Mellitus tipe II dengan gangguan ginjal. Pengambilan sampel berdasarkan lamanya waktu penelitian yaitu selama 3 bulan mulai bulan Januari-Maret 2016.

\section{ALAT}

Peralatan yang digunakan dalam penelitian ini adalah pulpen untuk menulis, lembar pengumpul data untuk menampung data rekam medik dan hasil wawancara dan rekam medik untuk menampung berkas dan dokumen mengenai catatan kesehatan pasien.

\section{HASIL}

\section{Karakteristik Pasien}

\section{a. Karakteristik Berdasarkan Jenis Kelamin}

Berikut ini disajikan tabel karakteristik dan diagram pasien Diabetes Mellitus tipe II dengan gangguan ginjal di instalasi rawat inap RSUD A.W.Sjahranie Samarinda selama bulan Januari-Maret 2016 dapat dilihat pada Tabel 1 dan Gambar 1.

\section{Tabel 1. Jenis kelamin pasien Diabetes Mellitus tipe II}

\begin{tabular}{ccccc}
\hline No & Jenis Kelamin & No Pasien & Jumlah Pasien & Persentase (\%) \\
\hline 1 & Pria & $2,3,15$ & 3 & $30 \%$ \\
2 & Wanita & $1,4,5,6,7,8,9$ & 7 & $70 \%$ \\
\hline
\end{tabular}

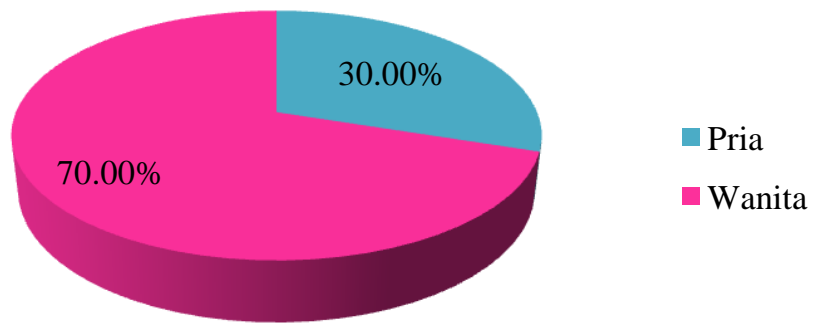

Gambar 1. Klasifikasi jenis kelamin pasien Diabetes Mellitus tipe II

Berdasarkan karakteristik dari jenis kelamin dapat di lihat bahwa, prevalensi kejadian DM Tipe II dengan gangguan ginjal pada wanita lebih tinggi dibandingkan pria, dengan 
persentase pada wanita sebesar $70 \%$ dan pada pria hanya sebesar $30 \%$. Hal ini dikarenakan wanita lebih beresiko mengidap Diabetes karena secara fisik wanita memiliki peluang peningkatan indeks masa tubuh yang lebih besar. Sindroma siklus bulanan (premenstrual syndrome), pasca-menopouse yang membuat distribusi lemak tubuh menjadi mudah terakumulasi akibat proses hormonal tersebut sehingga wanita berisiko menderita Diabetes Mellitus tipe II (Irawan, 2010).

\section{b. Karakteristik Berdasarkan Usia}

Usia merupakan salah satu faktor resiko Diabetes Mellitus tipe II dengan gangguan ginjal. Karakteristik pasien Diabetes Mellitus tipe II dengan gangguan ginjal di instalasi rawat inap RSUD A.W. Sjahranie Samarinda selama bulan Januari-Maret 2016 berdasarkan usia pada penelitian ini digolongkan menjadi tiga kelompok dapat dilihat pada Tabel 2 dan Gambar 2.

Tabel 2. Karakteristik usia pasien Diabetes Mellitus tipe II

\begin{tabular}{ccccc}
\hline No & Umur Pasien & No Pasien & Jumlah Pasien & Persentase (\%) \\
\hline 1 & $18-40$ tahun & 1,5, & 2 & $20 \%$ \\
2 & $41-60$ tahun & $2,3,4,6,7,8$ & 6 & $60 \%$ \\
3 & $>60$ tahun & 9,15 & 2 & $20 \%$ \\
\hline
\end{tabular}

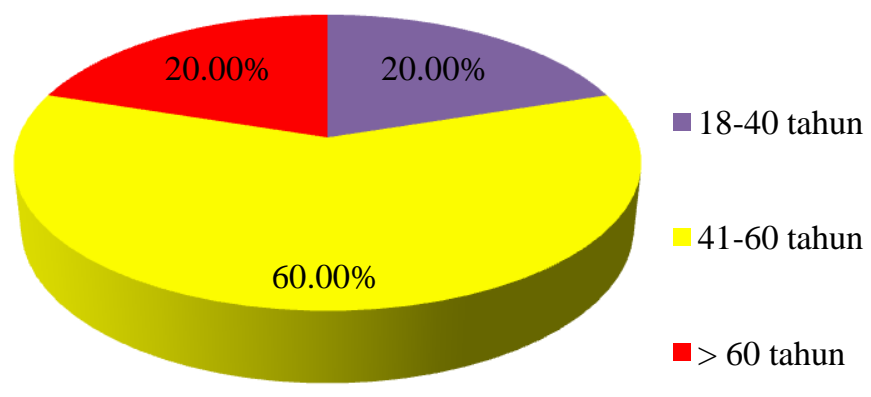

Gambar 2. Klasifikasi usia pasien Diabetes Mellitus tipe II

Kasus Diabetes Mellitus tipe II dengan gangguan ginjal di instalasi rawat inap RSUD A.W. Sjahranie Samarinda selama 3 bulan paling banyak terjadi pada usia 41-60 tahun yaitu sebanyak 6 pasien (60\%), persentase untuk usia 18-40 tahun dan usia $>60$ tahun masing-masing sebanyak 20\%. Data yang diperoleh sesuai dengan pernyataan dari American Diabetes Association (ADA) yang menyatakan bahwa usia diatas 45 tahun merupakan salah satu faktor resiko terjadinya penyakit Diabetes Mellitus tipe II (ADA, 2004). Orang yang mempunyai usia lebih dari 45 tahun dengan pengaturan diet glukosa yang rendah akan mengalami penyusutan sel-sel beta pankreas. Sel beta pankreas yang tersisa pada umumnya masih aktif, tetapi sekresi insulinnya semakin berkurang, selain itu kepekaan reseptornya mulai menurun yang mengakibatkan terjadinya hiperglikemia (Tjay, 2003). 


\section{c. Karakteristik Berdasarkan Riwayat Penyakit}

Tabel 7.3. Jenis dan persentase riwayat penyakit

\begin{tabular}{ccccc}
\hline No & Riwayat Penyakit & No Pasien & Jumlah Pasien & Persentase (\%) \\
\hline 1 & DM & $3,4,5,6$ & 4 & $40 \%$ \\
2 & DM + CKD st V & 2,8 & 2 & $20 \%$ \\
3 & DM + CKD st V + HT & 1 & 1 & $10 \%$ \\
4 & DM + CHF+ HT & 9,15 & 2 & $20 \%$ \\
5 & DM + HT & 7 & 1 & $10 \%$ \\
\hline
\end{tabular}

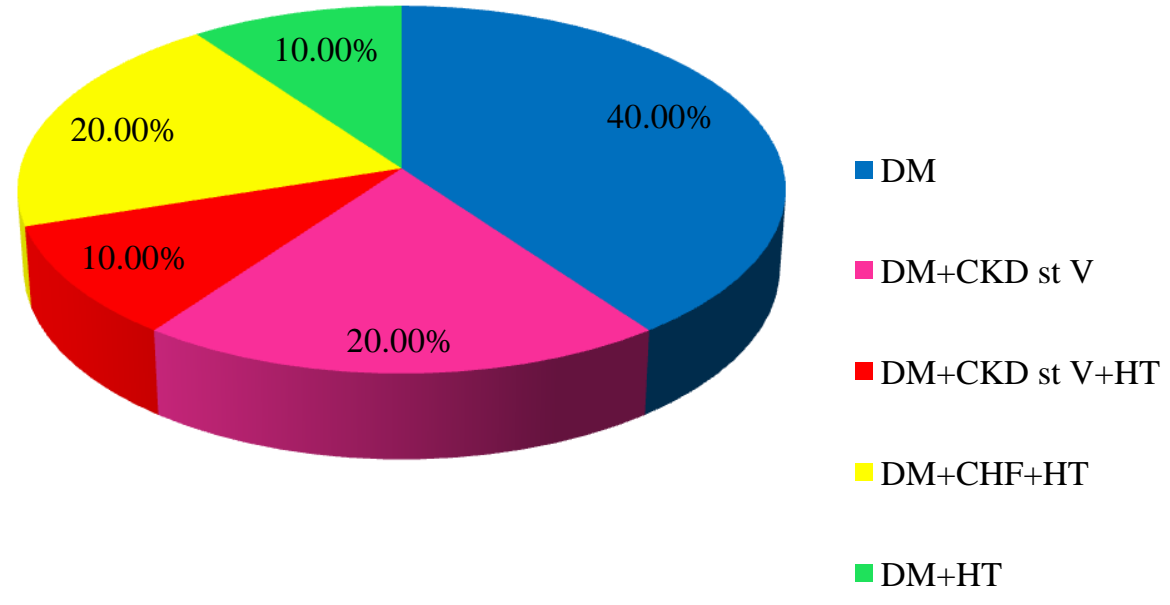

Gambar 3. Klasifikasi berdasarkan riwayat penyakit pasien Diabetes Mellitus tipe II

ket: $\mathrm{DM}=$ Diabetes Mellitus

CKD = Chronic Kidney Diseases

HT = Hipertention

$\mathrm{CHF}=$ Chronic Heart Failure

Riwayat penyakit merupakan salah satu faktor pemicu Diabetes Mellitus. Dari Tabel 3 dan Gambar 3 diperoleh data riwayat penyakit yang paling banyak terjadi pada pasien DM tipe 2 dengan gangguan ginjal di instalasi rawat inap RSUD A.W.Sjahranie adalah riwayat penyakit DM tanpa komplikasi sebesar $40 \%$, untuk riwayat penyakit komplikasi $\mathrm{DM}+\mathrm{CKD}$ st V dan DM+ CHF + HT masing-masing memperoleh persentase sebesar 20\%, sedangkan untuk riwayat penyakit komplikasi lain yaitu DM+CKD stV+HT dan DM+HT memiliki persentase masing-masing sebanyak $10 \%$.

Diabetes Mellitus merupakan penyakit degeneratif yang terjadi secara lambat (bertahuntahun) dan dapat terdeteksi bila muncul komplikasi penyakit lain. Pada pasien riwayat DM tanpa komplikasi dikatakan bahwa pasien tidak memiliki riwayat penyakit lain selain DM yang telah berlangsung selama bertahun-tahun tetapi baru saja mengalami komplikasi gagal ginjal. Riwayat DM ini bisa disebabkan oleh pengaruh faktor genetik. Bila terjadi mutasi gen maka dapat menyebabkan kekacauan metabolisme yang berujung pada 
timbulnya DM tipe 2 (Kaban, 2007). Resiko seseorang anak mendapat DM tipe 2 adalah $15 \%$ bila salah satu orang tuanya menderita DM. Jika kedua orang tua memiliki DM maka resiko untuk menderita DM adalah $75 \%$. Seseorang yang memiliki ibu dengan DM memiliki resiko 10-30\% lebih besar daripada seseorang yang memiliki ayah dengan DM. Hal ini dikarenakan penurunan gen sewaktu dalam kandungan lebih besar dari ibu (Diabetes UK, 2010).

Seseorang yang terkena Diabetes Melitus tidak dapat menggunakan glukosa secara normal dan glukosa akan tetap pada sirkulasi darah yang akan merusak jaringan. Kerusakan ini jika berlangsung kronis akan menyebabkan terjadinya komplikasi, seperti penyakit kardiovaskular, nefropati, retinopati, neuropati dan ulkus pedis (IFD, 2012). Salah satu riwayat penyakit pasien DM komplikasi adalah DM+CKD st $\mathrm{V}$ atau nefropati diabetik. Nefropati diabetik merupakan manifetasi mikroangiopati pada ginjal yang ditandai dengan adanya proteinuri (mulamula intermiten kemudian persisten), penurunan GFR ( glomerular filtration rate) peningkatan tekanan darah yang perjalanannya progresif menuju stadium akhir berupa gagal ginjal terminal. Pada pasien DM dengan gangguan ginjal terjadi kelainan glomerulus yang disebabkan oleh denaturasi protein karena tingginya kadar glukosa, hiperglikemia dan hipertensi intraglomerulus. Kelainan/ perubahan terjadi pada membran basalis glomerulus dengan proliferasi dari sel-sel mesangium. Keadaan ini akan dapat menyebabkan glomerulosklerosis dan berkurangnya aliran darah, sehingga terjadi perubahan-perubahan seperti pada permeabilitas membran basalis glomerulus yang ditandai dengan timbulnya albuminuria (Winarsi, 2010).

\section{d. Karakteristik Berdasarkan Lama Pasien Menderita DM}

Tabel 4. Lama waktu pasien menderita Diabetes Mellitus

\begin{tabular}{ccccc}
\hline No & $\begin{array}{c}\text { Lama Waktu Pasien } \\
\text { Menderita DM }\end{array}$ & No Pasien & Jumlah Pasien & Persentase (\%) \\
\hline 1 & $>1$ tahun & 15 & 1 & $10 \%$ \\
2 & $1-5$ tahun & $1,4,5,8,9$ & 5 & $50 \%$ \\
3 & $6-10$ tahun & 2 & 1 & $10 \%$ \\
4 & $11-15$ tahun & 3 & 1 & $10 \%$ \\
5 & $16-20$ tahun & 6 & 1 & $10 \%$ \\
6 & $>20$ tahun & 7 & 1 & $10 \%$ \\
\hline
\end{tabular}

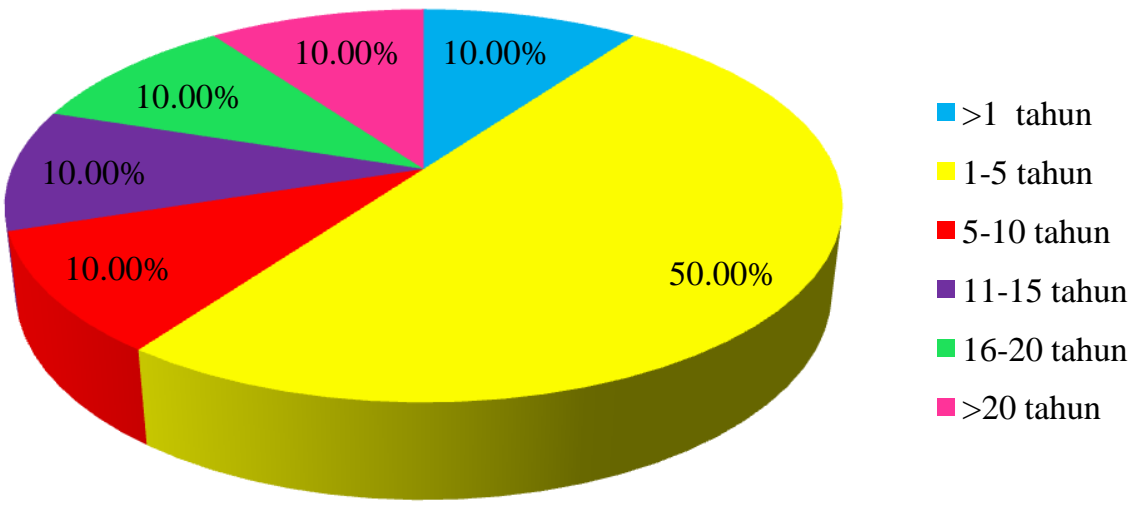

Gambar 4. Klasifikasi berdasarkan lama pasien menderita Diabetes Mellitus 
Berdasarkan hasil data karakteristik berdasarkan lama pasien menderita DM tipe 2, dapat diketahui bahwa pasien paling banyak menderita DM pada waktu 1-5 tahun sebesar $50 \%$. Diabetes Mellitus tipe 2 merupakan penyakit yang baru terdiagnosa saat telah timbulnya komplikasi yang terjadi selama bertahun-tahun. Akibat intoleransi glukosa yang berlangsung lambat (selama bertahun-tahun), dan progesif, maka penyakit DM dapat berjalan tanpa terdeteksi (Smeltzer, 2002).

\section{e. Karakteristik Berdasarkan Jenis Pekerjaan Pasien}

\section{Tabel 5. Jenis pekerjaan pasien Diabetes Mellitus}

\begin{tabular}{ccccc}
\hline No & Pekerjaan & No Pasien & Jumlah Pasien & Persentase (\%) \\
\hline 1 & IRT & $1,4,5,6,7,8,9$ & 7 & $70 \%$ \\
2 & Swasta & 2 & 1 & $10 \%$ \\
3 & Pensiun & 15 & 1 & $10 \%$ \\
4 & PNS & 3 & 1 & $10 \%$ \\
\hline
\end{tabular}

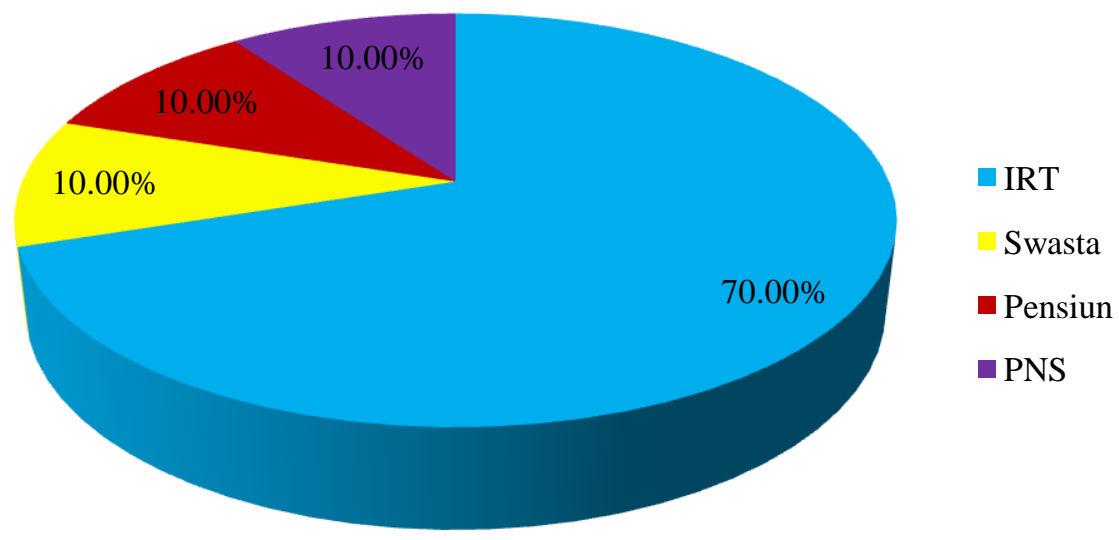

Gambar 5. Klasifikasi berdasarkan jenis pekerjaan pasien Diabetes Mellitus tipe II

Jenis pekerjaan juga erat kaitannya dengan kejadian Diabetes Mellitus. Pekerjaan seseorang mempengaruhi tingkat aktivitas fisiknya. Berdasarkan hasil data yang telah diperoleh dapat diketahui bahwa pasien Diabetes Mellitus tipe 2 dengan ginjal di isntalasi rawat inap RSUD A.W. Sjahranie Samarinda paling banyak memiliki pekerjaan sebagai Ibu Rumah Tangga (IRT) dengan persentase sebesar 70\%, sedangkan untuk pekerjaan swasta, pensiun dan PNS masing-masing memiliki persentase sebesar $10 \%$.

Aktivitas fisik dapat mengontrol sgula darah. Glukosa akan diubah menjadi energi pada saat beraktivitas fisik. Aktivitas fisik mengakibatkan insulin semakin meningkat, sehingga kadar gula dalam darah akan berkurang. Pada orang yang memiliki aktivitas yang rendah, misalnya ibu rumah tangga, maka zat makanan yang masuk ke dalam tubuh tidak dibakar tetapi ditimbun dalam tubuh sebagai lemak dan gula. Jika insulin tidak mencukupi untuk mengubah glukosa menjadi energi, maka akan timbul Diabetes Mellitus (Kemenkes, 2010). 


\section{f. Karakteristik Berdasarkan Jenis Pendidikan Terakhir Pasien}

Tabel 6. Jenis pendidikan terakhir pasien Diabetes Mellitus

\begin{tabular}{ccccc}
\hline No & Pendidikan Terakhir & No Pasien & Jumlah Pasien & Persentase (\%) \\
\hline 1 & SD & $1,4,5,8,9$ & 5 & $50 \%$ \\
2 & SMA & 6,7 & 2 & $20 \%$ \\
3 & D3 & 2,3 & 2 & $20 \%$ \\
4 & S1 & 15 & 1 & $10 \%$ \\
\hline
\end{tabular}

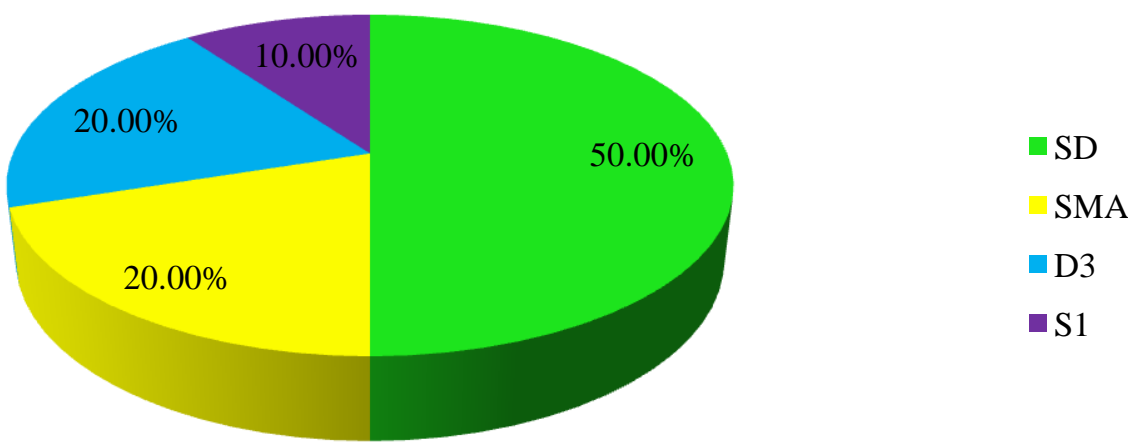

Gambar 6. Klasifikasi berdasarkan pendidikan terakhir pasien Diabetes Mellitus tipe II

Hasil data yang diperoleh menunjukkan bahwa pendidikan terakhir pasien Diabetes Mellitus tipe 2 dengan gangguan ginjal di instalasi rawat inap RSUD A.W.Sjahranie Samarinda adalah tamatan sekolah dasar (SD) dengan persentase sebesar 50\%, untuk pasien tamatan SMA dan diploma 3 (D3) masing-masing memperoleh persentase sebesar $2 \%$, serta pasien dengan tamatan S1 hanya sebesar $10 \%$.

Rendahnya tingkat pendidikan dan pengetahuan merupakan salah satu penyebab tingginya angka kasus suatu penyakit. Pengetahuan dapat diperoleh melalui promosi kesehatan (Notoadmojo, 1997). Promosi kesehatan yang meliputi pendidikan kesehatan, faktor ekonomi dan lingkungan yang mendukung terbentuknya perilaku yang sehat dan dapat menurunkan faktor resiko Diabetes Mellitus (Glanz, 1997).

Tingkat pendidikan memiliki pengaruh terhadap kejadian penyakit Diabetes Mellitus tipe II dengan gangguan ginjal. Orang yang memiliki pendidikan tinggi biasanya akan memiliki banyak pengetahuan tentang kesehatan. Dengan adanya pengetahuan tersebut, orang akan memiliki kesadaran dalam menjaga kesehatannya (Irawan, 2010).

Pola Pengobatan

Tabel 7. Karakteristik penggunaan kelas terapi obat

\begin{tabular}{|c|c|c|c|c|c|c|}
\hline No & Kelas Terapi & $\begin{array}{c}\text { Golongan } \\
\text { Obat }\end{array}$ & Jenis Insulin & No Pasien & $\begin{array}{c}\text { Jumlah } \\
\text { Pasien }\end{array}$ & $\begin{array}{c}\text { Persentase } \\
(\%)\end{array}$ \\
\hline & Antidiabetik & Insulin & Rapid Acting & $1,2,3,9$ & 4 & $40 \%$ \\
\hline 1 & & & $\begin{array}{l}\text { Rapid Acting + } \\
\text { Long Acting }\end{array}$ & $4,5,6,7,8,15$ & 6 & $60 \%$ \\
\hline
\end{tabular}




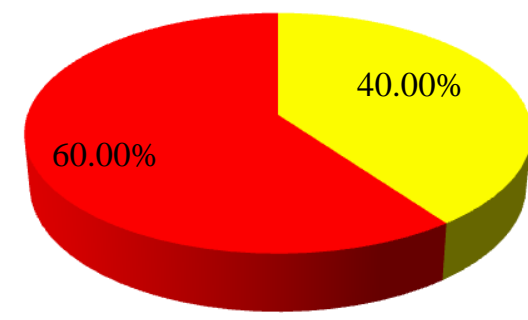

Rapid Acting

- Rapid Acting + Long Acting

Gambar 7. Karakteristik penggunaan insulin pada pasien DM tipe 2 dengan gangguan ginjal.

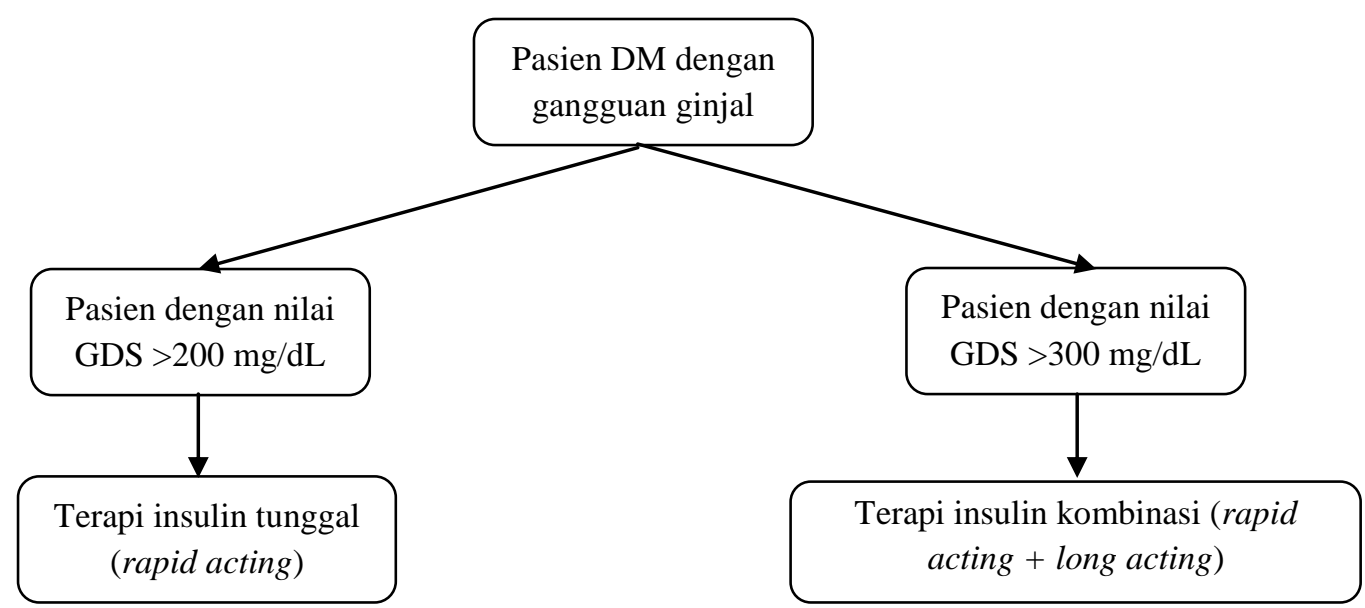

Gambar 8. Skema penggunaan insulin pada pasie DM tipe II dengan gangguan ginjal.

Terapi insulin pada DM tipe 2 dapat dimulai antara lain untuk pasien dengan kegagalan terapi oral, kendali kadar glukosa darah yang buruk (A1c > 7,5\%) atau kadar glukosa darah puasa $>250 \mathrm{mg} / \mathrm{dl}$ ) (Rismayanthi, 2010). Semua insulin dapat digunakan untuk pasien CKD dan tidak ada spesifik tentang pengggunaan dosis insulinnya. Jenis insulin, dosis dan penggunaannya harus disesuaikan dengan kondisi pasien hingga mencapai goal therapy tetapi tidak menyebabkan hipoglikemik.

Berdasarkan data dari tabel 7 dan gambar 7, dapat diketahui bahwa pada pasien DM tipe 2 dengan gangguan ginjal di instalasi rawat inap RSUD A.W. Sjahranie Samarinda paling banyak menggunakan terapi insulin tunggal Apidra dan insulin kombinasi Novorapid+Levemir sebanyak 30\%, untuk insulin kombinasi Apidra +Levemir memperoleh persentase sebesar 20\%. Sedangkan insulin kombinasi yang lain seperti Apidra+Lantus dan insulin tunggal Novorapid hanya digunakan oleh satu orang saja dengan persentase $10 \%$.

Insulin Apidra dan Novorapid termasuk dalam insulin rapid acting yang diabsorbsi cepat di dalam tubuh dan dapat menurunkan insulin secara cepat serta untuk kebutuhan insulin prandial. Insulin jenis ini memiliki onset kerja 5-15 menit dengan aksi puncak pada menit ke 30-90, dan durasi rata-rata selama 5 jam. Pada pasien CKD tahap 4-5 dan orangorang dialisis sering mengalami penundaan pengosongan lambung, sehingga perlu 
diberikan insulin rapid acting untuk mensesuaikan puncak insulin dengan waktu puncak glukosa darah postprandial (Hahr, 2015). Apidra merupakan salah satu insulin rapid acting yang paling banyak digunakan dengan dosis $0,5-1$ unit $/ \mathrm{kg} / \mathrm{hari}$ dan dapat digunakan 15 menit sebelum makan. Penggunaan insulin Apidra di indikasikan untuk pasien DM dengan gangguan ginjal yang memiliki nilai gula darah sewaktu (GDS) diatas $200 \mathrm{mg} / \mathrm{dL}$ tujuannya adalah untuk menurunkan gula darah dengan segera.

Pada kondisi pasien tertentu terapi insulin long acting digunakan dengan tujuan untuk mempertahankan insulin basal yang konstan. Insulin yang termasuk dalam kelompok ini adalah insulin Detemir (Levemir) dan Glargine (Lantus). Insulin long acting mulai berkerja 1-2 jam. Puncak efek obat hampir tidak ada atau merata selama 24 jam, dan efek obat akan berakhir sampai lebih dari 24 jam. Keuntungan insulin ini antara lain dapat digunakan sekali untuk 24 jam (1x1 hari pada malam hari) karena insulin ini hampir tidak ada puncak efek obat dan kemungkinan hipoglikemik pada malam hari bisa dikurangi (Tandra, 2007).

Novorapid merupakan tipe insulin yang bekerja cepat (rapid acting), insulin ini memungkinkan penggantian insulin pada waktu makan secara fisiologis karena mula kerjanya yang cepat, keuntungan lainnya yaitu karena insulin ini dapat diberikan segera sebelum makan tanpa mengganggu kontrol glukosa (Katzung, 2010). Berdasarkan gambar 7.2 yang menampilkan skema penggunaan insulin, diketahui bahwa dalam penggunaannya seseorang yang memiliki nilai gula darah sewaktu (GDS) $>200 \mathrm{mg} / \mathrm{dL}$ diberikan terapi insulin tunggal golongan rapid acting (contohnya Apidra ${ }^{\circledR}$ dan Novorapid®). Sedangkan untuk pasien dengan nilai GDS $>300 \mathrm{mg} / \mathrm{dL}$ maka diberikan terapi insulin kombinasi golongan rapid acting dan long acting (contohnya Lantus ${ }^{\circledR}$ dan Levemir®). Pada kondisi pasien dengan nilai GDS yang sangat tinggi perlu diberikan terapi kombinasi insulin rapid acting yang bekerja menurunkan gula darah dengan segera dan mengontrol gula darah saat makan, dan insulin long acting menjaga kondisi insulin basal pada saat malam hari agar gula darah tetap dalam kondisi stabil.

\section{DAFTAR PUSTAKA}

Diabetes, UK. 2010. Diabetes In The UK 2010: Key Statistics on Diabetes.

Glanz, K., F.M Lewis and B.K Rimer. 1997. Health Behavior and Health Education. Jossey-Bass Publisher: San Fransisco.

Hahr, Allson J and Mark E, Molitch. 2015. Management of Diabetes Mellitus in Patient With Chronic Kidney Disease. Clinical Diabetes and Endocrinology. Vol 1 No 2.

International Diabetes Federation (IDF). 2012. Diabetes Atlas 5th Edition. IDF: Belgium. Irawan, Dedi. 2010. Prevalensi dan Faktor Resiko Kejadian Diabetes Mellitus tipe 2 di Daerah Urban Indonesia (Analisa Data Sekunder Riskesda 2007). Jurnal Universitas Indonesia.Vol 1 No 1.

Kaban, Sempakata. 2007. Diabetes Tipe 2 di Kota Sibolga Tahun 2005. Majalah Kedokteran Nusantara. Volume 40 No 2.

Katzung, G. Betram. 2010. Farmakologi Dasar dan Klinik, Edisi 10. Salemba Medika: Jakarta.

Kementerian Kesehatan. 2010. Petunjuk Teknis Pengukuran Faktor Resiko Diabetes Mellitus.

Misnadiarly. 2006. Diabetes Mellitus: gangren, Ulcer, Infeksi. Mengenal Gejala, Menangulangi dan Mencegah Komplikasi Ed 1. Pustaka Populer Obor: Jakarta.

Notoadmojo, S. 1997. Ilmu Kesehatan Masyarakat (edisi pertama).Rineka Cipta: Jakarta.

Rismayanthi, C. 2010. Terapi Insulin Sebagai Alternatif Pengobatan Bagi Pengobatan Diabetes. Fakultas Pendidikan Kesehatan UI: Jakarta.

Smeltzer, S.C., and Bare, B.G. 2002. Keperawatan Medikal Bedah Bruner and Suddarth. Edisi 8 Volume 2. EGC: Jakarta. 
Tandra, Hans. 2007. Segala Sesuatu Yang Harus Anda Ketahui Tentang Diabetes. PT Gramedia Pustaka Utama: Jakarta.

Winarsi, Heri. 2010. Protein Kedelai dan Kecambah. Kanisius: Yogyakarta. 